\title{
Knowledge Base Design for Diagnosis Pregnancy Problems
}

\section{Perancangan Basis Pengetahuan untuk Diagnosa Permasalahan Gangguan Kehamilan}

\author{
Farah Rifdah Arzumni ${ }^{1}$, Rina Dewi Indahsari ${ }^{2}$ \\ [farahrifdah@gmail.com ${ }^{1}$, rinadewi@asia.ac.id ${ }^{2}$ ]
}

Program Studi Teknik Informatika, Fakultas Teknologi dan Desain, Institut Teknologi dan Bisnis Asia Malang

\begin{abstract}
In Indonesia, the death rate of pregnant women was still very high. Lack of knowledge about the perceived symptoms during pregnancy make pregnant women regardless of the specific symptoms that can be harmful and disease records indicate the causes of indirect maternal death in pregnant. Moreover, the risk of pregnant mother mortality is also higher due to the delay in taking the decision factors for referenced. Based on the fact, the proposed solution in the form of expert system diagnosis of diseases of pregnant women using the method of Backward Chaining that can help recognize diseases during pregnancy to take place based on the perceived symptoms of pregnant women as well as references that should be targeted by the patient. The methods of the Backward Chaining have a performance system that is capable of running the functional needs and high accuracy percentage results. With the existence of a system of experts on pregnancy problems that use the Backward Chaining method can describe the level of confidence of an expert on the problem at hand. Based on the test results, obtained results $100 \%$ functionality of disease diagnosis expert system of pregnant women worked in accordance with a list of system requirements and the system.
\end{abstract}

Keywords - pregnancy disorder diagnosi;, solution; expert system; backward chaining.

Abstrak. Di Indonesia, angka kematian ibu dan anak masih sangat tinggi. Kurangnya pengetahuan mengenai gejala yang dirasakan saat masa kehamilan membuat ibu hamil tidak menghiraukan gejala-gejala tertentu yang dapat mengindikasi penyakit berbahaya dan menjadi penyebab tidak langsung kematian ibu hamil. Selain itu, resiko kematian ibu juga semakin tinggi akibat adanya faktor keterlambatan mengambil keputusan untuk dirujuk. Berdasarkan hal tersebut, diusulkan solusi berupa sistem pakar diagnosa gangguan kehamilan pada ibu hamil menggunakan metode Backward Chaining yang dapat membantu mengenali gangguan kehamilan selama kehamilan berlangsung berdasarkan gejala-gejala yang dirasakan ibu hamil serta tempat rujukan yang harus dituju oleh pasien. Metode Backward Chaining memiliki kinerja sistem yang mampu berjalan sesuai kebutuhan fungsional dan hasil presentase akurasi tinggi. Dengan adanya sistem pakar masalah kehamilan yang menggunakan metode Backward Chaining dapat mengambarkan tingkat keyakinan seorang pakar terhadap masalah yang sedang dihadapi. Berdasarkan hasil pengujian, diperoleh hasil 100\% fungsionalitas sistem pakar diagnosa gangguan kehamilan pada ibu hamil berjalan sesuai dengan daftar kebutuhan sistem.

Kata Kunci - Diagnosis gangguan kehamilan; Solusi; Sistem Pakar; Backward Chaining.

\section{PENDAHULUAN}

Proses kehamilan umumnya terjadi selama 9 bulan 10 hari, dihitung dari proses pembuahan sampai persalinan. Proses menanti kelahiran calon buah hati menjadi hal yang banyak dinantikan oleh semua pasangan suami istri. Selama 9 bulan ibu mengandung janin di dalam perutnya merupakan suatu kebahagiaan yang tidak terhingga. Susrama [3] mengatakan bahwa banyak masalah yang menyebabkan angka kematian persalinan cukup tinggi. Pertama masih banyak yang mengatasi masalah kesehatan tersebut dengan jalan tradisional yang tidak jarang kontra-produktif dengan keadaan tubuh, sehingga bila sudah parah baru datang ke dokter. Kedua, para wanita masih malu dan tertutup untuk berkonsultasi secara langsung mengenai kesehatan pribadi. Terlebih sebagian besar dokter obstetri dan ginekologi adalah kaum pria. Dan yang ketiga karena kurangnya informasi mengenai kesehatan obstetri dan ginekologi.

Saat ini masih banyak ibu hamil mengalami gangguan kehamilan yang sering diabaikan. Kebanyakan ibu hamil jarang memeriksakan kandungannya karna beranggapan kandungannya tidak mengalami masalah dan baik-baik saja. Ketika ada posyandu ibu-ibu hamil pun enggan datang untuk memeriksakan kandungannya yang seharusnya diwajibkan untuk diperiksa oleh tenaga medis setempat. Sehingga para tenaga medis cukup kesusahan dalam menangangi ibu-ibu hamil tersebut. Seharusnya ibu-ibu hamil tersebut menyadari pentingnya memeriksakan kandungannya serta mengerti hal apa yang harus di lakukan jika mengalami gangguan kehamilan. Sebagian besar ibuibu hamil baru pergi ke rumah sakit ketika sudah mengalami gangguan kehamilan yang kritis.

Dalam hal ini sistem pakar adalah sistem yang menggunakan pengetahuan, fakta dan teknik penalaran dalam memecahkan masalah yang biasanya hanya dapat dipecahkan oleh seorang pakar dalam bidang tertentu [1]. Menyikapi 
kondisi ibu-ibu hamil yang ada di indonesia yang belum mengerti pentingnya memeriksakan kandungannya kepada tenaga medis yang ada di lingkungan mereka, sistem pakar ini bisa membantu memecahkan dan menyelesaikan masalah yang sering di hadapi oleh para tenaga medis untuk membantu para ibu hamil untuk lebih banyak mengetahui tentang kehamilan mereka. Implementasi sistem pakar dipandang sebagai cara penyimpanan pengetahuan pakar dalam bidang tertentu kedalam program komputer sedemikian rupa sehingga dapat memberikan keputusan dan melakukan penalaran secara cerdas [7]. Dalam Penelitian ini akan digunakan metode penalaran backward chaining untuk menentukan diagnose permasalahan gangguan kehamilan.

Pada penalaran mundur (Backward Chaining), inference engine memilih suatu aturan dan menganggapnya sebagai masalah yang harus diselesaikan [5]. Dengan menggunakan perangkat aturan inference engine mulai mengevaluasi dari variabel sasaran, kemudian diikuti dengan pemilihan salah satu submasalah untuk dievaluasi, dan submasalah yang terpilih akan dievaluasi sebagai masalah baru [2]. Inference engine terus mencari submasalah untuk menjadi masalah baru yang akan dievaluasi sampai dengan tidak ada lagi submasalah yang ditemui. Penalaran maju bergerak lebih cepat dari penalaran mundur karena penalaran mundur tidak harus mempertimbangkan semua aturan dan tidak membuat beberapa putaran melalui perangkat aturan [4]. Penalaran mundur sangat sesuai digunakan jika :

a. Terdapat variabel sasaran berganda (multiple goal variable)

b. Terdapat banyak aturan.

c. Semua atau hampir semua aturan tidak harus diuji dalam proses mencapai pemecahan

\section{METODE PERANCANGAN}

Tahap- tahap dalam perancangan aplikasi ini adalah sebagai berikut:

1. Survey

Berfungsi untuk mengetahui kebutuhan pemakai, kesalahan-kesalahan dalam sistem lama, menetapkan tujuan perancangan, mengajukan usulan otomasi sistem yang layak dan dapat diterima serta menyiapkan laporan survey yang berisi segala sesuatu pada point diatas.

2. Analisa Sistem

Menggabungkan laporan survey dan kebijakan pemakai menjadi spesifikasi yang terstruktur dengan menggunakan pemodelan.

3. Desain

Mengimplementasikan model yang diinginkan pemakai.

4. Implementasi

Mempresentasikan hasil desain ke dalam pemograman .

5. Uji coba desain

Menguji coba seluruh spesifikasi terstruktur.

6. Testing terakhir

Menguji coba sistem secara keseluruhan.

7. Deskripsi Prosedur

Pembuatan laporan teknis tertulis seperti petunjuk pemakaian dan pengoperasian aplikasi.

8. Instalasi

Aspek terakhir yang mesti dilakukan mencakup serah terima aplikasi dan pelatihan pemakaian.

9. Perawatan

Pemeliharaan perangkat lunak secara berkesinambungan.

\section{PERANCANGAN BASIS PENGETAHUAN}

Perancangan sistem pakar ini menggunakan metode Backward Chaining. Langkah-langkah dalam penerapan metode ini bisa di mulai dengan membuat Knowledge-Based System (KBS) yang mempunyai lima langkah dalam pembuatannya, yaitu [8][10] :

1. Melakukan Isolasi area Permasalahan

2. Menentukan Target Keputusan

3. Membuat Diagram Ketergantugan

4. Membentuk Tabel kenputusan

5. Membuat Rule IF-THEN

Langkah pertama yaitu melakukan isolasi area permasalahan. Dari lingkup masalah kehamilan meliputi tanggalan yang digunakan untuk menentukan HPL (Hari perkiraan Lahir), Keluhan terhadap gangguan kehamilan serta 
informasi seputar kehamilan. Dalam Penelitian ini akan dibatasi permasalahan pada keluhan terhadap gangguan kehamilan saja serta menentukan solusi yang tepat untuk mengatasi gangguan tersebut. Diagram isolasi area ditunjukkan oleh gambar 1 .

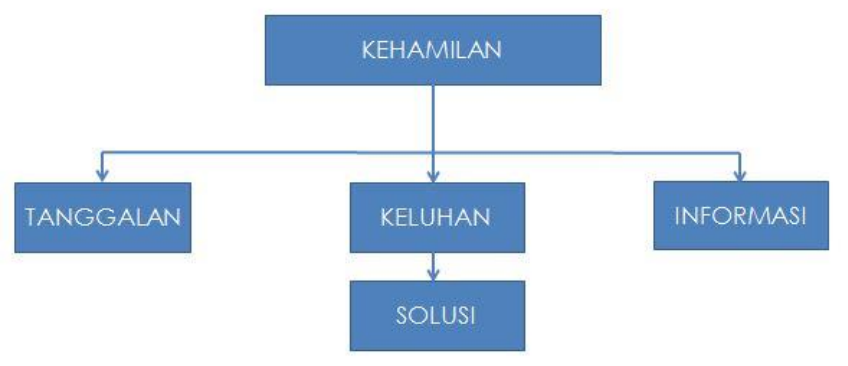

Gambar 1. Isolasi Area Permasalahan Gangguan Kehamilan

Setelah permasalahan dibatasi, langkah selanjutnya adalah menentukan target keputusan pada sistem pakar. Ibu Hamil pada umumnya membutuhkan bantuan untuk kasus gangguan yang diderita dan ingin mengetahui bagaimana caranya untuk mengatasi gangguan tersebut. Penanganan berkelanjutan dari gangguan yang diderita mungkin membutuhkan informasi atau layanan lain. Karena itu dapat ditentukan 3 hal yang menjadi target keputusan yaitu solusi secara umum untuk penanganan gangguan kehamilan [6][9]:

1. Solusi 1

Cara mengatasinya ibu hamil dapat menghindari makanan yang menganduk lemak, istirahat teratur, banyak minum cairan dan frekuensi makan ditingkatkan meskipun dalam jumlah yang kecil, beristirahat atau berendam menggunakan air hangat untuk membantu mengurangi rasa pegal. Hindari untuk memijat, ibu hamil yang ingin memilih relaksasi dengan memijat berkonsultasi terlebih dahulu dengan dokter dan juga pilih ahli pijat khusus ibu hamil dan peranan suami untuk dapat mendampingi, menanyakan keluhan dan memahami kondisi istri.

2. Solusi 2

Olahraga ringan dan mengatur berat badan. Minum air yang banyak pada pagi hingga sore hari, namun saat mendekati waktu tidur, jangan minum terlalu banyak. Mengepit guling dan mengganjal pinggang dengan bantal juga bisa membuat ibu hamil untuk tidur lebih nyaman.

Dianjurkan untuk banyak minum, mengkompres dingin, memakai sepatu longgar dan meninggikan kaki pada saat duduk atau istirahat. Ibu dapat mencegah terjadinya sakit kepala dengan mengkonsumsi makanan yang sehat, teratur, meningkatkan asupan cairan, beristirahat dan juga menghindari stres.

Banyak mengonsumsi makanan berserat, seperti buah-buahan dan sayur-sayuran, sangat disarankan untuk mengatasi sembelit. cobalah untuk beristirahat duduk atau berbaring segera dan konsumsi makanan-makanan yang bergizi dan hindari gerakan tiba-tiba ke posisi tegak untuk mengurangi risiko.

Cobalah untuk menghindari posisi tidur yang salah, lakukan posisi tidur tegak lurus. Buat jadwal yang teratur. Mengatur waktu tidur dan bangun akan membantu ibu untuk tidur dan bangun pada jam yang sama setiap harinya. Untuk mempermudah tertidur, usahakan agar ibu tenang dan rileks.

3. Solusi 3

Keluhan ini harus segera dikonsultasikan dengan dokter atau bidan untuk mengetahui kondisi kehamilan anda dan tidak membahayakan untuk janin dan kesehatan ibu hamil. Anda perlu segera berkonsultasi pada tenaga medis untuk mendapatkan penanganan secepatnya. 


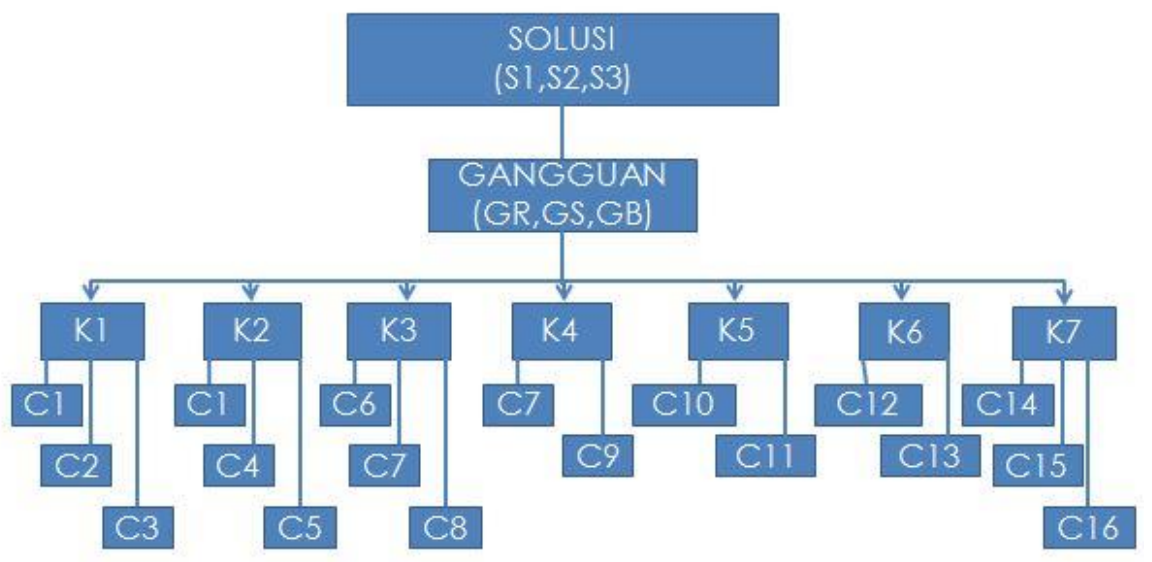

Gambar 2. Target Keputusan Permasalahan Gangguan Kehamilan

Gambar 2 menunjukkan kerangka pengambilan keputusan terhadap solusi dari permasalahan gangguan kehamilan. Solusi ditentukan berdasarkan jenis gangguan yang dialami yaitu bisa jadi GR (Gangguan Ringan), GS (Gangguan Sedang) atau GB (Gangguan Berat). Jenis gangguan ditentukan berdasarkan 7 hal yaitu K1, K2, K3, K4, K5, K6 dan K7. Masing-masing Kn memiliki sub kriteria yaitu mulai C1 sampai C16. Ketergantungan antara kriteria tersebut ditunjukkan pada diagram ketergantungan di gambar 3. Dimana terdapat Sembilan factor kritis yang disimbolkan dengn segitiga. Sehingga terdapat 9 rule set yang akan terbentuk.

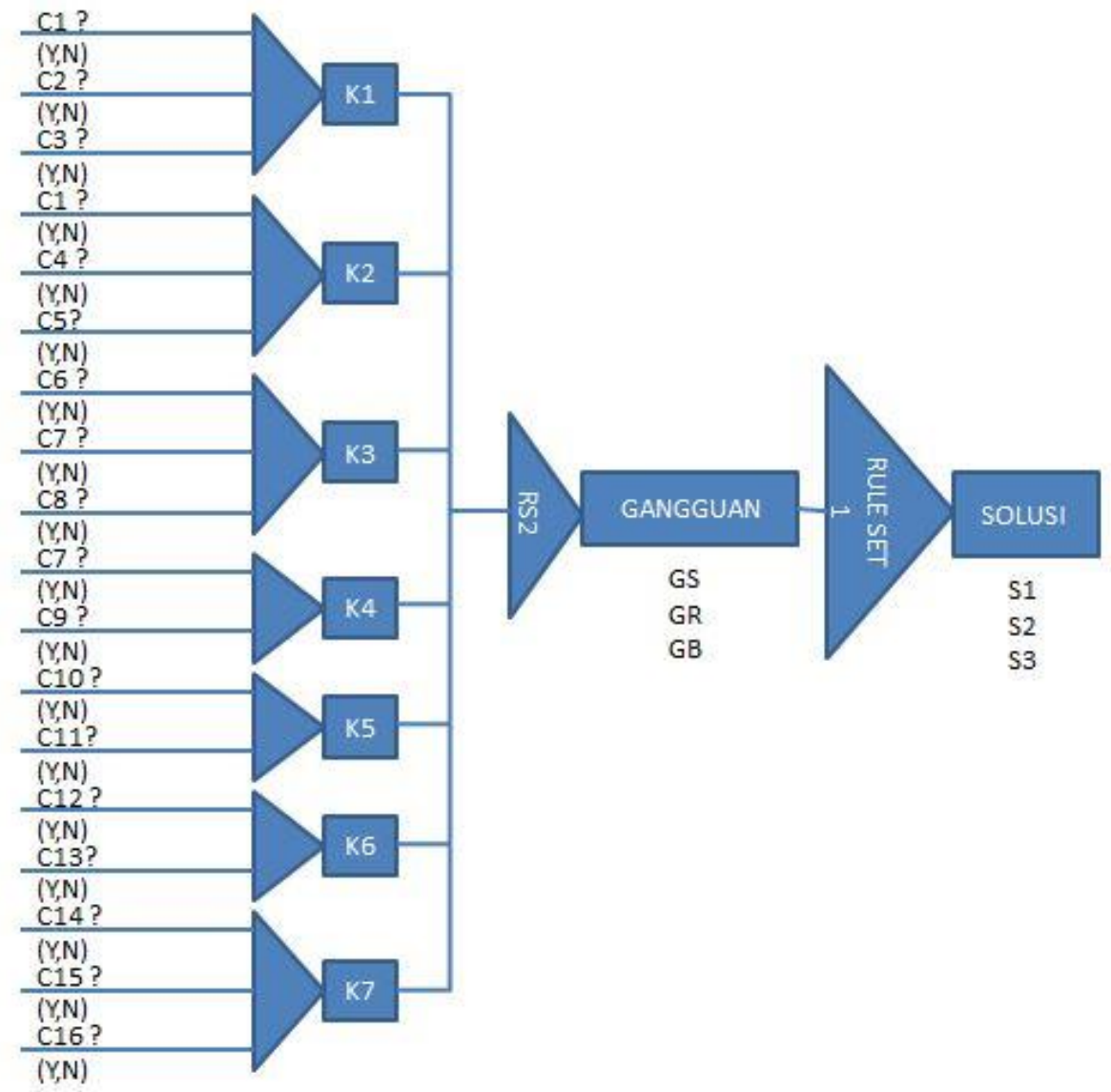

Gambar 3. Diagram ketergantungan Permasalahan Gangguan Kehamilan

Selanjutnya akan dibentuk rule setnya melalui table keputusan. Tabel keputusan diturunkan dari dependency diagram pada Gambar 3. Karena dalam gambar tersebut terdapat 9 segitiga, maka akan terdapat 9 tabel keputusan. Prosesnya diawali dengan membuat plan rule setnya, kemudian membuat table keputusan lengkap, melakukan 
penyederhaan (reduksi) table keputusan dan yang terakhir menuliskan rulenya. Plan set untuk rule set ditunjukkan pada table 1.

Tabel 1. Plan Rule Set 1

\begin{tabular}{|c|c|c|}
\hline Atribut & Value Atribut & Jml value \\
\hline Gangguan & (GR, GS, GB) & 3 \\
\hline \multicolumn{3}{|c|}{ Jumlah baris=3 } \\
\hline
\end{tabular}

Pada rule set 1 hanya memiliki 1 atribut saja yaitu gangguang dengan 3 value atribut. Karena hanya ada 1 input atribut, maka table keputusan lengkap yang terbentuk dengan 3 baris tidak perlu lagi membutuhkan proses penyederhanaan (reduksi tabel). Sehingga bisa langsung dituliskan hasil rule IF-Then dari rule set 1 yaitu menghasilkan 3 rule yang ditunjukkan pada table 2. Dimana masing-masing rule menghasilkan target keputusan solusi yang berbeda-beda yaitu S1, S2 dan S3.

Tabel 2. IF-Then Rule Set 1

\begin{tabular}{|l|l|}
\hline R1 & IF GANGGUAN=GR THEN SOLUSI=S1 \\
\hline R2 & IF GANGGUAN= GS THEN SOLUSI $=$ S2 \\
\hline R3 & IF GANGGUAN=GB THEN SOLUSI $=S 3$ \\
\hline
\end{tabular}

Proses akan berlanjut untuk rule set 2 sampai dengan rule 9 dengan tahapan proses yang sama dengan rule set 1 . Pada permasalahan gangguan kehamilan ini diperoleh 57 rule dari 9 rule set yang ada. Jumlah rule dari masing-masing set ditunjukkan pada table 3 berikut.

Tabel 3. Hasil Jumlah Rule yang dihasilkan

\begin{tabular}{|c|c|c|}
\hline Set & RULE & JUMLAH RULE \\
\hline Set \#1 & R 1-3 & 3 \\
\hline Set \#2 & R 4-20 & 17 \\
\hline Set \#3 & R 21-27 & 7 \\
\hline Set \#4 & R 27-34 & 7 \\
\hline Set \#5 & R 34-41 & 7 \\
\hline Set \#6 & R 42-44 & 3 \\
\hline Set \#7 & R 45-47 & 3 \\
\hline Set \#8 & R 48-50 & 3 \\
\hline Set \#9 & R 51-57 & 7 \\
\hline \multicolumn{2}{|c|}{ TOTAL RULE } & 57 \\
\hline
\end{tabular}

Rule yang dihasilkan ini untuk selanjutnya disimpan dalam basis pengetahuan dan digunakan dalam proses reasoning oleh inference engine untuk menarik kesimpulan dalam proses konsultasi. Untuk permasalahan diagnose sangat cocok digunakan metode backward chaining dalam menarik kesimpulannya.

\section{KESIMPULAN}

Bedasarkan hasil pembahasan pada Penelitian ini mengenai penerapan sistem pakar untuk mendiagnosa masalah kehamilan dengan menggunakan backward chaining, maka dapat di ambil kesimpulan bahwa : Untuk hasil rule set yang baik, dalam proses perancangan basis pengetahuan harus melalui tahapan secara runut yaitu dimulai dari deskripsi permasalahan yang ada dengan mengumpulkan informasi dari pakar, membatasi permasalahan dengan menentukan isolasi area, menentukan target keputusan dan atribut apa saja yang mempengaruhi pengambilan keputusan tersebut, membuat diagram ketergantungan dan tahap terakhir adalah membentuk rule dengan table keputusan. Permasalahan gangguan kehamilan ini termasuk permasalahan diagnose, sehingga metode inferensi yang paling cocok adalah backward chaining, karena pencarian dalam backward chaining diawali dengan membukti sebuah goal dari sekumpulan fakta yang telah diketahui. Metode Backward Chaining dapat membantu mengenali gangguan kehamilan selama kehamilan berlangsung berdasarkan gejala-gejala yang dirasakan ibu hamil serta memiliki kinerja sistem yang mampu berjalan sesuai kebutuhan fungsional dan hasil presentase akurasi tinggi. Dengan adanya sistem pakar masalah kehamilan yang menggunakan metode Backward Chaining ini dapat mengambarkan tingkat keyakinan pakar terhadap masalah yang sedang dihadapi karna hasil pengujian, diperoleh hasil $100 \%$ fungsionalitas sistem pakar 
Procedia of Engineering and Life Science Vol. 1. No. 2 Juni 2021

Seminar Nasional \& Call Paper Fakultas Sains dan Teknologi (SENASAINS $2^{\text {nd }}$ )

Universitas Muhammadiyah Sidoarjo

diagnosa gangguan kehamilan pada ibu hamil berjalan sesuai dengan daftar kebutuhan sistem dan sistem mempunyai tingkat akurasi sebesar $100 \%$.

\section{REFERENSI}

[1] Bagus Prabowo, Ardian. Sistem Pakar Untuk Mendiagnosa Penyakit Infeksi Saluran Pernafasan Akut (ISPA) Berbasis Web. Member, IEEE, Jakarta. 2015

[2] Kusrini. Sistem Pakar Teori dan Aplikasi. Andi Yogyakarta, 2006

[3] Dinda Dwi Ratnasari, Sutariyani. Sistem Pakar Diagnosa Gangguan Kehamilan Dengan Metode Forward Chaining. STMIK AUB Surakarta. 2015

[4] Farizi, Anif. Sistem Pakar Untuk Mendiagnosa Kerusakan Komputer Dengan Menggunakan Metode Forward Chaining. Jurusan Teknik Elektro, Fakultas Teknik, Universitas Negeri Semarang. 2014

[5] Iriani, Siska. Penerapan Metode Backward Chaining pada Sistem Pakar Diagnosa Penyakit Tulang Manusia. STKIP PGRI Pacitan. 2015

[6] Kementerian Kesehatan RI. Buku Kesehatan Ibu dan Anak (BKIA). Jakarta. Kementerian Kesehatan dan JICA (Japan International Cooperation Agency). 2016

[7] Lestari D. Jurnal: Definisi sistem pakar. Arsip Teknik Informatika UMMI. 2012

[8] Kusrini, Aplikasi Sistem Pakar Menentukan Faktor Kepastian Pengguna dengan Metode Kuantifikasi Pertanyaan, Andi, Yogyakarta, 2008

[9] Manuaba dkk. Ilmu kandungan, penyakit kandungan dan KB. Jakarta: EGC. 2010

[10] Nurhasanah, Fujiansyah. Pembuatan Sistem Pakar Untuk Memprediksi Awal Penyakit Gigi dan Mulut Berbasis Web Dengan Metode Backward Chaining. Prosiding Seminar Nasional Ilmu Komputer Universitas Diponegoro. Semarang, 2010 